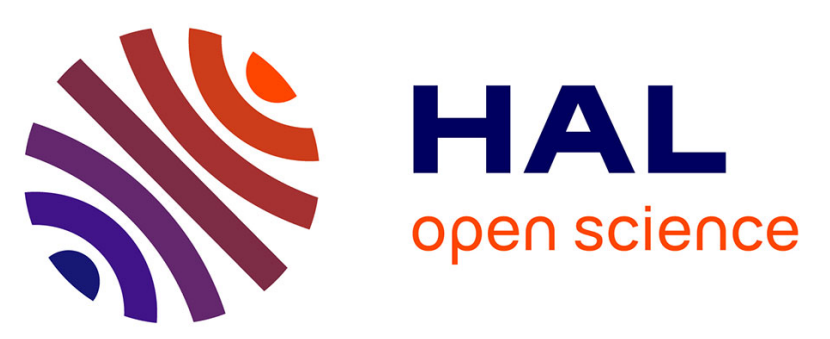

\title{
ANDRA underground research laboratory: interpretation of the mineralogical and geochemical data acquired in the Callovian-Oxfordian formation by investigative drilling
}

Eric C. Gaucher, Christian Robelin, J.M Matray, Gabrielle Negrel, Yves Gros, J.F. Heitz, Agnès Vinsot, H. Rebours, Alain Cassagnabère, Alain Bouchet

\section{To cite this version:}

Eric C. Gaucher, Christian Robelin, J.M Matray, Gabrielle Negrel, Yves Gros, et al.. ANDRA underground research laboratory: interpretation of the mineralogical and geochemical data acquired in the Callovian-Oxfordian formation by investigative drilling. Physics and Chemistry of The Earth, 2004, 29 (1), pp.55-77. 10.1016/j.pce.2003.11.006 . hal-00664755

\section{HAL Id: hal-00664755 \\ https: / hal-brgm.archives-ouvertes.fr/hal-00664755}

Submitted on 31 Jan 2012

HAL is a multi-disciplinary open access archive for the deposit and dissemination of scientific research documents, whether they are published or not. The documents may come from teaching and research institutions in France or abroad, or from public or private research centers.
L'archive ouverte pluridisciplinaire HAL, est destinée au dépôt et à la diffusion de documents scientifiques de niveau recherche, publiés ou non, émanant des établissements d'enseignement et de recherche français ou étrangers, des laboratoires publics ou privés. 
ANDRA UNDERGROUND RESEARCH LABORATORY: INTERPRETATION OF

THE MINERALOGICAL AND GEOCHEMICAL DATA ACQUIRED IN THE CALLOVIAN-OXFORDIAN FORMATION BY INVESTIGATIVE DRILLING

E. Gaucher ${ }^{1, \#}$, C. Robelin ${ }^{1}$, JM Matray ${ }^{2 *}$, G. Négrel ${ }^{2}$, Y. Gros ${ }^{2}$, J.F. Heitz ${ }^{2}$, A. Vinsot ${ }^{3}$, H. Rebours ${ }^{3}$, A. Cassagnabère ${ }^{4}$, A. Bouchet ${ }^{4}$.

1: BRGM, Orléans-45 (France); 2: ANTEA, Orléans-45 (France); 3: ANDRA, Bure55 (France); 4: ERM, Poitiers-86 (France); " author to whom the correspondence should be addressed; *: present address: IRSN, Fontenay-aux-Roses-92 (France).

e.gaucher@brgm.fr

c.robelin@,brgm.fr

jean-michel.matray@irsn.fr

g.negrel@antea.brgm.fr

agnes.vinsot@andra.fr

herve.rebours@andra.fr

alain.cassagnabere@erm.univ-poitiers.fr

alain.bouchet@erm.univ-poitiers.fr fax :33238 6430 62;

fax : 33238643399

fax : 33158358130 ;

fax 33238643390 ;

fax ; 33329755389 ;

fax : 33329755389 ;

fax : 335494540 26;

fax : 33549454026 


\begin{abstract}
Under the ANDRA Meuse/Haute Marne underground research laboratory scientific programme, two boreholes (EST204 and EST205) were drilled to a depth of $510 \mathrm{~m}$ for the purposes of scientific characterization. Twenty-nine core samples were taken in borehole EST205 every $3 \mathrm{~m}$ between 422 and $504 \mathrm{~m}$ depth. Physical property measurements (water content, porosity, density, specific surface), geochemical analyses (major and trace elements, cation exchange capacity [CEC] and surface cation occupancy, leaching anions, redox state, organic matter concentration), and a semi-quantitative mineralogical study were conducted on the samples.
\end{abstract}

As the rocks are in a reduced state, the core samples were stored under nitrogen immediately after drilling. All the steps of the sampling and of the characterisation are done with a research of limitation of the oxidation to obtain representative samples of the in situ conditions.

The top of the formation is more carbonate-rich, with interbedded clayey layers and carbonate rock. The formation is more homogeneous in its central section with a clay mineral concentration of $45-50 \%$, which corresponds to a maximum of flooding within the area. In the upper part of this section, micas and mixed-layer illite/smectite R0 dominate, whereas in the lower part of the section we find an abrupt transition to mixed-layer illite/smectite R1 associated with kaolinite.

A statistical analysis, including the data of major and trace elements with the semiquantitative mineralogy, enabled the identification of some mineralogical traps for trace elements. The values of cation occupancy at the surface of the clay minerals provided a 
good image of the pore water chemistry; pore water is in equilibrium with the clay surfaces. Leaching experiments revealed the pore water salinity and provided profiles of $\mathrm{Cl}$ and $\mathrm{Br}$ concentrations. $\mathrm{Cl} / \mathrm{Br}$ values in the centre of the formation are close to the present-day seawater ratio, which could indicate a seawater origin of the pore water. Some measurements of total reduced capacity, provide quantified results of the reduced state of the rock.

Processing the data on water content, helium and petroleum pycnometry enabled calculation of total rock porosity and gave an uncertainty range for this value. Finally, the high $\operatorname{BET}\left(\mathrm{N}_{2}\right)$ specific surfaces are consistent with the clayey nature of the rock.

\section{KEYWORDS:}

Callovian, Oxfordian, Jurassic, Bure, France, claystone, shale, mineralogy, geochemistry

\section{INTRODUCTION}

\subsection{Context of the study}

The Agence Nationale de Gestion des Déchets Radioactifs (ANDRA - French National Radioactive Waste Management Agency) is building an underground research laboratory (URL) in the commune of Bure (northeastern, France), to investigate the disposal of radioactive wastes in a deep clayey formation. The main gallery of the laboratory is located in Callovian-Oxfordian host rock at an approximate depth of $490 \mathrm{~m}$. The underground laboratories are essential equipments to characterise the properties of the host rocks (geology, geomechanics, mineralogy, and geochemistry) at a large scale and to perform in situ experiment to assess the disposal concepts. The first investigation of plastic mudrocks by in situ measurements was the 'Hades' URL constructed in 1983 at Mol in 
Belgium (Beaufrays et al. 1994). The indurate mudrocks have been characterised in a disused railway tunnel at Tournemire (southern France, De Windt et al. 1998) and at the Mont Terri URL (Jura, Switzerland, Thury and Bossart, 1999, Pearson et al., 2003). A synthesis of the previous works made in mineralogy and geochemistry in clayey URLs can be found in Bath et al. 2001.

As part of the scientific investigations accompanying the construction of the ANDRA URL, two 510-m-deep boreholes (EST204 and EST205) were drilled on the access shaft sites of the laboratory before any large-diameter excavation began. These boreholes allowed an accurate geological survey, and the retrieval of samples for off-site mineralogical and geochemical analyses and geomechanical tests. The boreholes and associated scientific investigations were completed between June and October 2000 (Bertrand et al., 2001). Stopping at a depth of $510 \mathrm{~m}$, they only intersected the Oxfordian units of the formation. Previous surveys were conducted in 1994 to 1996 (EST103/104).

The aim of this paper is to present the geochemical and mineralogical results for the Oxfordian units of the host formation, chiefly obtained during drilling of the EST205 borehole. The novelty of this presentation resides in the large body of uniform data acquired from the huge number of undisturbed samples (1 sample every $3 \mathrm{~m}$ between 422 and $510 \mathrm{~m}$ depth), thereby allowing a very detailed description of this formation.

The techniques employed were selected with feedback from similar operations conducted by ANDRA for the ARCHIMEDE project at Mol (Griffault et al., 1997) and MONT TERRI (Pearson et al., 2003), and also during previous work on the MSE101, HTM102 and EST104 deep boreholes of the Bure site (ANDRA, 1999). 


\subsection{Geologic setting}

The Paris Basin is a subcircular intracratonic basin, currently bordered by the much older Ardennes in the northeast, the Vosges to the east, the Morvan to the southeast, the Massif Central to the south and the Armorican Massif to the west.

The eastern part of the Paris Basin has a cuesta morphology, resulting from a slightly (1 to $2^{\circ}$ ) westward dipping monoclinal structure. The Callovian-Oxfordian formation is therefore marked in the topography by a classic trilogy:

- $\quad$ The Woevre plain depression in Late Callovian and Early to Middle Oxfordian clayey formations;

- $\quad$ The Meuse cuesta, underlain by Middle to Late Oxfordian limestone;

- $\quad$ The backslope of the Meuse cuesta, overlain by Kimmeridgian marl/limestone.

Andra's Bure site is located on the backslope of another cuesta, underlain by the Barrois limestones, of latest Kimmeridgian to Tithonian age.

At Bure, the Callovian-Oxfordian argillite (conventionally referred to as $\mathrm{C} 2$ ) is about $130 \mathrm{~m}$ thick. Four lithostratigraphic units are identified, subscripted C2a to C2d, from base to top. Only the upper three units of Oxfordian age ( $\mathrm{C} 2 \mathrm{~b}$ pro parte, $\mathrm{C} 2 \mathrm{c}$ and $\mathrm{C} 2 \mathrm{~d})$, identified by a detailed survey, are dealt with here. The sedimentary series is primarily clayey in the bottom two-thirds, and becomes progressively siltier, and then increasingly calcareous towards the top. A remarkable sedimentological surface is associated with the maximum clay zone (MCZ, 489-486 m): the maximum flooding surface (MFS) of the Callovian-Oxfordian cycle. This cycle marks the transition from transgression at the base to a regression, which led to the installation of the Oxfordian carbonate platforms. The top of the clayey formation is located at a depth of around $417 \mathrm{~m}$, overlain by $243 \mathrm{~m}$ of Middle and Late Oxfordian limestone. $175 \mathrm{~m}$ of Kimmeridgian marl and limestone, capped by the Barrois limestone of Kimmeridgian age (Fig. 1) of which only the base is 
exposed at the site follow this. The clayey formation is separated from the Dogger limestone by a regional paleo-erosion surface.

Figure 1. Lithostratigraphic section

\section{MATERIALS AND METHODS}

\subsection{CORING, PRESERVATION AND SAMPLE PREPARATION}

To obtain uncontaminated samples during coring, it was necessary to select a chemically inert drilling fluid for claystone, containing additives tending to reduce or prevent interactions (inhibitors). Water-based muds are unsuitable due to swelling of the clays and the presence of water. An oil-based mud was selected, consisting of $80 \%$ by volume of oil (gas-oil containing $0.4 \%$ aromatics) and $20 \%$ brine $\left(\mathrm{CaCl}_{2}, 350 \mathrm{~g} / \mathrm{l}\right)$. The oil and brine mix forms an emulsion whose high $\mathrm{Ca}$ content prevents swelling of the clay minerals. The addition of $\mathrm{CaCO}_{3}$ to the mud helps to obtain densities above 1.1 necessary for coring in clayey formations. Figure 2 shows the aspect of cores extracted from the same stratigraphic level in the EST204 and EST205 boreholes, respectively, after 10 months of storage. EST204 was drilled with a water-based mud that caused the clays to swell and the core to fracture, after which the drilling mud penetrated into the fractures. The core obtained from the EST205 borehole using an oil-based mud is still intact. Consequently, the EST205 borehole was selected as the reference for acquisition of the data.

\section{Figure 2}

Furthermore, the oil film coating the cores protected them against drying and oxidation until their packaging under nitrogen atmosphere. The large core diameter $(152.4 \mathrm{~mm})$ 
allowed us to cut away the oil-contaminated surface and only to select the perfectly protected central cores for analysis.

The cores were immediately conditioned after leaving the core sampler. This involved a double envelope of heat-sealed plasticized aluminium, first purged of atmospheric gases with a vacuum pump and then filled with nitrogen. The packages remained under a nitrogen overpressure and were stored and transported in an icebox at $4{ }^{\circ} \mathrm{C}$.

Analyses vulnerable to oxidation were prepared and were carried out completely in a glove box under nitrogen.

\subsection{ANALYTICAL TECHNIQUES}

Petrographic characterization and identification of the minerals were carried out by optical microscopy (Olympus BH-2), scanning electron microscopy (SEM - Jeol JSM 6400) and X-ray diffraction (XRD - Siemens D500). Minerals identified by XRD under the term "mica + illite" include muscovite, biotite, illite and possibly glauconite sensu stricto (Figs. 14 and 15). Given the relatively broad width of the characteristic XRD peaks, illite may be mixed-layer in illite/smectite rich in illite ( $>90 \%$ illite). The semi-quantitative estimation of the different minerals identified by XRD was carried out by a standard calculation based on chemical analysis of the rock, CEC measurements and the carbonate content. The method employed was similar to that described by Calvert et al. (1989). Calculations were performed using chemical compositions of minerals published in the literature (Newman and Brown, 1987 and Weaver, 1989, for micas, illite and I/S ordered and disordered; Deer et al., 1992, for the other minerals). The range of mineral proportions was considered satisfactory when the calculated proportions agreed with the maximum of analytical data. We must observe that the accuracy of the mineral proportions is not the same according to the phase considered. Thus the proportions of minerals like pyrite, apatite/collophane and titanium oxides can be determined with a relative accuracy of about 
$10 \%$ on the characteristic element $(\mathrm{S}, \mathrm{P}$ and $\mathrm{Ti})$ by chemical analysis performed on the total rock, this means $\pm 0.05 \%$ for a measured value of $0.5 \%$. Similarly, calcimetry helps to determine the proportions of carbonates with an absolute accuracy of \pm 1 to $2 \%$. On the other hand, Reynolds (1989) stated that even if many characteristic parameters (chemistry and crystallography) of the clay minerals to be quantified are known, an absolute uncertainty of $\pm 5 \%$ remains.

Carbonate contents were measured by calcimetry in the laboratory (ERM 29 samples) and on site (GEO-RS 100 samples). In the discussion, the complete set of data is taking into account.

Laser granulometry (Malvern Master sier IP) was carried out after acid attack (addition of $\mathrm{N} / 2 \mathrm{HCl}$ up to a $2<\mathrm{pH}<4$ ) to eliminate the carbonate cement and to promote the dispersion of mineral phases after the addition of $\mathrm{Na}$ hexametaphosphate and ultrasonic treatment for $40 \mathrm{~s}$. Particle-size data (29 samples) were processed to determine the proportions of sand, silt and clay. The average contents per unit are given in Table 2. The cut-off values used for these sand-silt and silt-clay boundaries are $63 \mu \mathrm{m}$ and $4 \mu \mathrm{m}$ respectively according to Wentworth size classification (Petitjohn et al., 1972).

The porosity of the argillite samples was characterised in several ways. The first was direct measurement by $\mathrm{Hg}$ injection (Micromeritics Autopore III 9410 V1.02). This does not allow quantification of pores smaller than $3 \mathrm{~nm}$.

Density measurements were taken in three ways:

- Measurement of the water content at $150{ }^{\circ} \mathrm{C}$ under a vacuum guarantees that a reference anhydrous state has been reached, which is not the case at $105^{\circ} \mathrm{C}$, a temperature at which clays retain a large share of their water of hydration.

- He pycnometry is used to measure the dry density of the rock (Micromeritics 1305 pycnometer). 
- Kerosene immersion pycnometry helps to determine the wet density of the rock.

The combination of water content and the two pycnometry values helps to characterise the rock porosity.

The specific surface area was measured for this study by the conventional BET method with nitrogen absorption (Micromeritics ASAP 2010 v4.00 E).

The overall analysis of the major- and trace-elements was carried out by X-ray fluorescence spectrometry.

The elementary analysis of characteristic minerals was carried out systematically by analysis with the EDX probe of the SEM. This probe was validated on a large number of standard minerals. Thus over a concentration range from $3 \%$ to $45 \%$, it is possible to achieve an accuracy of $0.3 \%$. Final validation was carried out on standard orthoclase, and the results obtained are given in Table A1 in the appendix. These analyses directly give the chemical compositions of the major- and trace-minerals, cements and matrices, of all the samples taken.

The leachable anions $\left(\mathrm{Cl}, \mathrm{SO}_{4}, \mathrm{PO}_{4}, \mathrm{I}_{\text {tot }}, \mathrm{F}\right)$ were analysed by ionic chromatography and $\mathrm{Br}$ by ICP-MS (detection limit: $1 \mu \mathrm{g} / \mathrm{l}$ ) in a batch experiment obtained after $24 \mathrm{hrs}$ of interaction ( $20 \mathrm{~g}$ of powdered sample in $200 \mathrm{~g}$ of ultrapure water degassed with $\mathrm{N}_{2}$ ). Most of the elements analysed in the rock-leach waters are disturbed by the dissolution of component minerals. Only the halides $(\mathrm{Cl}, \mathrm{Br}, \mathrm{I})$ and, in certain cases, sulphates and fluorides, are representative of the pore water chemistry. This group of ions is potentially inherited from the history of the geological formation without interaction with the rock. In certain cases, however, iodides could have been affected by redox mechanisms, fluorides by fluorine dissolution and sulphates both by redox reaction and sulphates bearing phases dissolution. 
The total-reducing capacity (TRC) of all reducing species was quantified roughly during oxidation of the sample by potassium dichromate $\left(3 \mathrm{hrs}-150^{\circ} \mathrm{C}\right)$ after sulphuric acid attack. The TRC represents a measurement of the "oxidisability" of the rock.

The analysis of organic matter was limited to 2 parameters (Shimadzu TOC carbon analyser): total organic carbon (TOC) and dissolved organic carbon (DOC). DOC was measured during leaching, after filtration at $0.2 \mu \mathrm{m}$. TOC was measured after attack with hot, dilute hydrochloric acid to eliminate carbonates. The suspension was filtered and the residue dried for analysis as total carbon. This was oxidised in $\mathrm{CO}_{2}$ by heating in an oxygen stream and the quantity liberated was measured by infrared spectrometry. The relative uncertainty is $10 \%$ for values in the range of $1 \%$.

Measurements of Cation Exchange Capacity (CEC) and adsorbed-cation populations were carried out previously (ANDRA, 1999) by exchange with $\mathrm{NH}_{4}, \mathrm{Mg}$ and $\mathrm{Cs}\left(\mathrm{CH}_{3} \mathrm{COONH}_{4}\right.$, $\mathrm{MgCl}_{2}, \mathrm{CsCl}$ ). The results were difficult to use for exchangeable cations. In fact, calcite and dolomite strongly dissolve in ammonium acetate. The measurement of $\mathrm{MgCl}_{2}$ also raises the problem of the inability to determine the quantity of exchangeable Mg. Finally, the types of adsorbed cation population were not identified in the experiment with $\mathrm{CsCl}$ ANDRA (1999). For this study, cobaltihexamine chloride was used, as this displays greater affinity for the exchange sites of clays than $\mathrm{NH}_{4}, \mathrm{Mg}$ and $\mathrm{Cs}$. This technique also helps to determine ammonium naturally adsorbed on the clay. 


\section{RESULTS AND INTERPRETATION}

\subsection{MINERALOGY, LITHOLOGY, AND PARTICLE SIZE DISTRIBUTION}

\subsubsection{GEOCHEMICAL CHARACTERISTICS OF MINERALS}

\section{Phyllosilicates}

Biotite and muscovite of detrital origin display different states of preservation. Local analyses (EDS) reveal that the dioctahedral potassium micas fit into a range of chemical compositions that is very close to a theoretical muscovite. Muscovite is thus very little altered. This is not the case for biotite for which the composition range spreads between biotite sensu stricto (without reaching the domain of fresh biotite) and chlorite. Biotite is thus considered to be chloritised to varying degrees (Fig. 3). Detrital chlorite in fairly large particles $(50 \mu \mathrm{m})$ can be distinguished from chloritised biotite. Analyses reveal trioctahedral chlorite rich in iron close to the ferriferous pole of chamosite-type chlorite. A small shift of the peak at $14 \AA$ is observed with XRD, implying an mixed-layer chlorite/smectite very rich in chlorite. Glauconite is observed as green granules $(50 \mu \mathrm{m})$ under the optical microscope. With EDS analyses, these granules show chemical composition consistent with the literature.

Kaolinite is only absent up to $453.7 \mathrm{~m}$ depth. Two swelling clays were detected by $\mathrm{XRD}$. These are mixed-layer illite/smectite of the $\mathrm{I} / \mathrm{S}_{\mathrm{R} 0}$ type, which are totally replaced by $\mathrm{I} / \mathrm{S}_{\mathrm{R} 1}$ between 489.2 and $493.47 \mathrm{~m}$ depth. In the $\mathrm{I} / \mathrm{S}_{\mathrm{R} 0}$, the smectite content ranges between 40 and $70 \%$ and in the $\mathrm{I} / \mathrm{S}_{\mathrm{R} 1}$ the smectite content ranges between 20 and $50 \%$.

Figures 3 and 4 


\section{Carbonates}

Calcite is the most abundant carbonate. It is found in euhedral crystals, as sparitic secondary cement and as fossil tests usually in the form of fragments.

Other types of secondary carbonate were found, characterised by euhedral recrystallization distinguished from calcite by high magnesium and (locally) iron contents. Qualitative analyses of these carbonates show that they do not have the $(\mathrm{MgO}+\mathrm{CaO}) / \mathrm{CaO}$ mass ratio of stoichiometric dolomite $\mathrm{CaMg}\left(\mathrm{CO}_{3}\right)_{2}$. Hence they are not dolomite sensu stricto but carbonate called calcium-rich dolomite or magnesian-calcite. These carbonates have a crystal lattice similar to that of dolomite with a composition $\mathrm{Ca}_{1+\mathrm{x}}, \mathrm{Mg}_{1-\mathrm{x}}\left(\mathrm{CO}_{3}\right)_{2}$. Dolomite indexed on XRD diagrams corresponds to these phases, which are not stoichiometric dolomite.

Certain samples contain zoned calcium-rich dolomite (Fig. 5). Such zoning is due to variations in magnesium content while preserving the crystallographic directions of the crystal. The $\mathrm{CaO} /(\mathrm{MgO}+\mathrm{CaO})$ ratio of these recrystallised carbonates, if it fluctuates, reveals no significant depth variations. The carbonates of the five deepest samples (Est05703, Est05712, Est05724, Est05738 and Est05748) are very rich in iron, indicating ferriferous ankerite or even siderite.

\section{Figure 5}

\section{Silicates}

Quartz is present in various forms (rounded, angular, elongate or spherical, with sharp or dull fractures) indicating their detrital origin (Fig. 4). Their size varies considerably, from a few to more than fifty microns. SEM reveals rare authigenic silica that crystallised in pores or replaced carbonates of fossil tests. These are forms of low-temperature silica: 
either $\alpha$-quartz or chalcedony (Opal-CT). In a semi-quantitative estimate, the different forms of crystalline silica are combined under the term "quartz".

\section{Sulphides}

Three types of sulphide were identified, pyrite which is the most abundant; sphalerite (ZnS), identified in a few samples, locally in combination with pyrite (Est05681, Est05724 and Est05748); chalcopyrite (CuFeS2) identified only in sample Est05666.

As a rule, pyrite is fairly abundant in the studied samples, occurring as isolated euhedral crystals, clusters without any particular form, and as pseudomorphs of bioclasts, but the most common are framboids (Figs. 6 and 4).

No trace of typical weathering minerals affecting the pyrites was identified.

\section{Figure 6}

\section{Feldspars}

Feldspars were found in certain samples as detrital grains, with slightly rounded edges (rare euhedral forms). They do not display well-expressed dissolution patterns (Fig. 4) and are mainly potassium feldspar of the orthoclase type. Albite was identified in samples EST 055460 (429.6 m), Est05554 (451.9 m), and Est05546 (453.7 m). Chemical compositions are consistent with those of the different minerals given in the literature. For example, the $\mathrm{Na}$ and $\mathrm{K}$ feldspars of sample Est05546, display $\mathrm{Si} / \mathrm{Al}$ atomic ratios of 3, the $\mathrm{Si} / \mathrm{Na}$ atomic ratio of Na-feldspar is 2.3 , and the $\mathrm{Si} / \mathrm{K}$ ratio of $\mathrm{K}$-feldspar is 3.7. These feldspars can be considered as rather well preserved

\section{Ca phosphates}

The calcium phosphates identified and analysed on the different samples reveal $\mathrm{P}_{2} \mathrm{O}_{5} / \mathrm{CaO}$ mass ratios close to those of collophane $\left\{\mathrm{Ca}_{3} \mathrm{P}_{2} \mathrm{O}_{8} \cdot n \mathrm{nH}_{2} \mathrm{O}\right\}$ at the top of the formation. Note that "collophane" is employed in the literature in a broad sense to include calcium phosphates of vague composition and variable crystallinity. The deepest samples display 
ratios closer to that of apatite $\left\{\mathrm{Ca}_{5}\left(\mathrm{PO}_{4}\right)_{3}(\mathrm{OH})\right\}$. No $\mathrm{F}$ or $\mathrm{Cl}$ enrichment of the phosphates was noted.

\section{Other trace minerals}

Titanium oxides (rutile/anatase) are not abundant, although they are found throughout the borehole. Ilmenite $\left(\mathrm{FeTiO}_{3}\right.$, ) was found in samples Est05441, Est05505 and Est05523.

Celestite, strontium sulphate, is identified in two samples (Est05554 and Est05632; Fig. 7). Celestite is an accessory mineral of calcareous rock, commonly associated with dolomitisation mechanisms.

\section{Figure 7}

\subsubsection{LITHOLOGY, AND PARTICLE SIZE DISTRIBUTION}

For each of the three lithostratigraphic units $\mathrm{C} 2 \mathrm{~b}, \mathrm{C} 2 \mathrm{c}$ and $\mathrm{C} 2 \mathrm{~d}$, starting with the oldest, the results are presented in connection with the vertical mineralogical changes and observed particle size distributions.

\section{Figure 8}

Tables 1-2

\subsubsection{UNIT C2B: LOWER OXFORDIAN (SUB-UNITS C2B1 AND C2B2)}

\section{Sub-unit C2b1: 510 to $473.8 \mathrm{~m}$}

This is a uniform stack of silty and calcareous argillites. Fossils are rare, (pelagic lamellibranchs, benthic foraminifera, siliceous sponges, ammonites and belemnites). The rock is dark grey to greenish; contains, in decreasing order, clay minerals, carbonates, quartz and accessory minerals. 
The clay minerals are a mixture of mixed-layer illite/smectite and illite, accompanied by small amounts of kaolinite and chlorite (Table 1). The proportion of clay minerals reaches a peak (49\%) between 489.11 and $485.97 \mathrm{~m}$. It is in the lower portion of the maximum clay zone (MCZ) that the proportions of illite (group), kaolinite and chlorite are the highest (17 to $21 \%, 3$ to $5 \%$ and 2 to $3 \%$ respectively). The mixed-layer illite/smectite, in contents between 20 and $24 \%$, are exclusively ordered type $\left(\mathrm{I} / \mathrm{S}_{\mathrm{R} 1}\right)$.

Above the MCZ, illite only accounts for 9 to $13 \%$ of the rock. Kaolinite and chlorite are $<2 \%$. An inversion occurs in the population of mixed-layer minerals: the ordered minerals $\left(\mathrm{I} / \mathrm{S}_{\mathrm{R} 1}\right)$ have disappeared in favour of disordered type $\left(\mathrm{I} / \mathrm{S}_{\mathrm{R} 0}\right)$

In the dark rock, slightly lighter beds indicate marly zones that are more calcareous. Under the MCZ, the rock is more calcareous (mean: 27\%, ranging from 17 to $41 \%$ ). Above, it is less so (mean: $24 \%, 16 \%$ to $33 \%$ ). Calcite very largely predominates among the calcareous minerals. It is present in the rock matrix, as fine micrite crystals intimately mixed with the clays. Another, smaller, portion results from organism tests. The calcite is accompanied by small amounts $(<5 \%)$ of magnesian carbonates (calcic dolomite or magnesian calcite) and ferriferous carbonates (ankerite or siderite). The latter are more abundant below the MCZ.

The quartz increases upward. Below the MCZ, the mean value is $19 \%$ and increases to $25 \%$ above.

Accessory minerals $(<5 \%)$ accompany the main minerals (feldspars, rutile, anatase, ilmenite, celestite, pyrite, sphalerite, chalcopyrite and phosphate minerals). Only pyrite appears to be ubiquitous.

\section{Figure 9}


The silty fraction $[4-63 \mu \mathrm{m}]$ predominates in the rock (average 40\%). The proportion of clays $[<4 \mu \mathrm{m}]$ is smaller (average $34 \%$ ). The sandy fraction $[63 \mu \mathrm{m}-2 \mathrm{~mm}]$ is minute (1\%) (Table 2).

A coarsening of trend is identified from the base to the top of sub-unit C2b1. This is primarily explained by a slight enrichment (about $2 \%$ ) in silt, between the lower portion (39\% under the MCZ) and the upper portion (41\% above the MCZ). At the same time, the proportion of sand increases slightly, even exceeding $1 \%$ in the upper portion. The clay fraction fluctuates, but is lower in the upper portion.

Granulometrically, the average composition of the rock thus appears to be that of a clayey siltite that is calcareous to varying degrees. Mineralogically, however, it is a moreor-less calcareous quartz-rich argillite. This difference is probably due to the fact that about $10 \%$ of the clay particles are larger than $4 \mu \mathrm{m}$, and are thus included within the silt fraction, with quartz and accessory minerals. This is the case, for example, of glauconites (in granules of 20 to $80 \mu \mathrm{m}$ ), micas (in flakes often larger than $10 \mu \mathrm{m}$ ) and kaolinite (in tablets or booklets exceeding $10 \mu \mathrm{m})$. Conversely, the sum of the "clay" grain size fraction includes fine particles (quartz, feldspars, and pyrite).

\section{Sub-unit C2b2: 473.8 to $456 \mathrm{~m}$}

On the whole, the facies is continuous with that of the underlying rock: calcareous and pyritic silty argillite, dark grey, slightly bioturbated.

-At the base, from 472 to $468 \mathrm{~m}$, and at the top, between 459 and $456 \mathrm{~m}$, the rock is more calcareous, lighter in colour. The carbonate enrichment is progressive and does not give rise to the formation of calcareous beds.

-between 467 and $464 \mathrm{~m}$, lamination are pronounced with quartz-rich calcareous laminae and clayey laminae. 
Some of the mineralogical and grain size developments initiated above the MCZ continue, while others are reversed.

\section{Mineralogy}

Figure 8 shows how the proportion of clay minerals in the rock (43\%) decreases slightly compared with the figure recorded in the upper portion of $\mathrm{C} 2 \mathrm{~b} 1(45 \%)$. This decrease mainly results from the drop in the contents of interlayer disordered illite/smectite $\left(\mathrm{I} / \mathrm{S}_{\mathrm{R} 0}\right)$, which drop from 31 to $27 \%$. This drop is only partly offset by an increase in the proportion of illite from 11 to $13 \%$. Both kaolinite and chlorite contents remain below $2 \%$.

The carbonate content, dropping in the previous episode, increases from 25 to $27 \%$. This trend accentuates up to the cover of the host rock. The measured increase is mainly associated with a stronger presence of magnesian and ferriferous carbonates $(7 \%)$.

\section{Particle size distribution of the non-calcareous fraction}

Figure 9 shows a coarsening-up trend. In sub-unit $\mathrm{C} 2 \mathrm{~b} 1$, it primarily results from the increase in silt content and, to a lesser degree, the decrease in the clay proportion. Very slight sand enrichment occurs (Table 2). In C2b2, the coarsening-up effect is chiefly due to a decrease $(3 \%)$ in the share of clay. In other words, the rock does not really become coarser grained (silt-sand) towards the top. It becomes less clayey.

\subsubsection{UNIT C2C: 456 TO $437.80 \mathrm{M}$}

The series assumes a more alternating character. The dark, commonly laminated, calcareous silty argillite becomes enriched in carbonates, in numerous poorly delimited and lighter levels (marl). Banks of clayey bioclastic, bioturbated, locally silicified limestone, or 
bioclastic calcarenite, around $10 \mathrm{~cm}$ thick, with vague boundaries and nodular jointing appear in the upper portion. The fossil content appears to be more abundant, particularly in the more calcareous levels at the top (oysters, brachiopods, echinoderms).

The average values that have to assess these trends must nonetheless be regarded with caution. This is because the number of samples is small (7), except for the carbonates (27).

\section{Mineralogy}

The mean proportion of clay minerals is only $33 \%$, less than that measured in sub-unit $\mathrm{C} 2 \mathrm{~b} 2(43 \%)$. This primarily results from the sharp decrease in the contents of interlayer $\mathrm{I} / \mathrm{S}_{\mathrm{R} 0}$, going from 27 to $18 \%$. The kaolinite disappears. Illite and chlorite contents remain stable. The carbonate content increases sharply reaching $41.4 \%$ on average, following the increase of the share of calcite only.

\section{Particle size distribution of the non-calcareous fraction}

The silty fraction decreases sharply $(-8 \%)$ but remains predominant $(32.8 \%)$ compared to clays $(27 \%)$. The sand fraction drops by half, going from $2 \%$ to $1 \%$. The silt proportion thus becomes lower than that of carbonates (41\%). The siliciclastic load of the rock, which decreases, thus becomes slightly less coarse-grained (Table 4; Fig. 7).

A comparison of mineralogical and particle-size results identifies the following facts (Fig. 10):

- The proportion of mineralogical clay decreases, as well as that of grain size clay;

- Quartz content is stable. Normally, this should imply the stability of silt content, largely accounted for by this mineral, but, on the contrary, the silt fraction decreases sharply $(-8 \%)$. 
As a first hypothesis, this means that the decrease of the silt share in the rock is chiefly due to a rarefaction of the other minerals present in this fraction (kaolinite, micas, glauconite and perhaps a certain quantity of interlayer illite/smectite $\mathrm{I} / \mathrm{S}_{\mathrm{R} 0}$ ?).

\section{Fig 10}

\subsubsection{UNIT C2D: 437.80 TO $417.70 \mathrm{M}$}

In this essentially marly succession (Fig. 7), three successive zones appear:

- The base, between 437.80 and $434.8 \mathrm{~m}$, appears more calcareous, with a silt-clay limestone facies, medium grey colour, highly bioturbated;

- Then, up to $421.35 \mathrm{~m}$, the silty marls alternate, but poorly delimited, seams that are calcareous to varying degrees, up to several decimeters thick;

- In the upper portion, from $421.35 \mathrm{~m}$, delimited beds of clayey partly silicified bioclastic limestone appear. They are $10 \mathrm{~cm}$ thick, with nodular jointing and are strongly bioturbated.

\section{Mineralogy}

The quantities of non-calcareous minerals mentioned below are only indicative. They are calculated from only 5 samples. One of them was taken from a silty limestone sampled at $429.6 \mathrm{~m}$. Given the high proportion of carbonates $(75 \%)$ this bed tends towards an underestimation of the proportions of the other minerals in the mean calculated for the unit.

The mean carbonate content indicated is more representative, because it was calculated on 23 samples (5 analysed in the laboratory, and 18 calcidolomimetric measurements on site). 
The mean proportion of clay minerals has also dropped sharply from 33 to 20\% (Table 2).

Chlorite is only locally present. The illite content has dropped by half (from 13 to $6 \%$ ). The proportion of mixed-layer $\mathrm{I} / \mathrm{S}_{\mathrm{R} 0}$ has fallen by nearly one-third (from 18 to $13 \%$ ).

The mean carbonate content is globally stable with a greater depletion of calcite (from 38 to $33 \%$ ), not offset by the doubling of the magnesian minerals content (from 3 to $6 \%$ ).

The rock has become quart-rich (30\%), up nearly $4 \%$ ( $8 \%$ if one ignores the silty limestone bank sampled at $429.6 \mathrm{~m})$.

According to its mean mineralogical composition, the typical facies in this unit is hence that of a quartz-rich marl.

\section{Particle size distribution of the non-calcareous structure}

The silt content of the rock has dropped sharply from 33 to $23 \%$ (Table 2; Fig. 9). The clay content settles around $27 \%, 13 \%$ less in proportion than the measure in unit C2c. The proportion of sand remains stable (1\%).

A comparison of mineralogy and particle-size results (Fig. 10) reveals a quartz content exceeding the sum of silt and sand fractions. This suggests that the large-sized clay particles that they contained in the underlying units are absent. It also seems probable that a part of the quartz detected is present as very fine particles, included in the $<4 \mu \mathrm{m}$-size fraction.

\subsection{PHYSICAL PROPERTIES}

\section{Figure 11}

For the formation as a whole, the water contents are range from 6 to $9 \%$ (mass water content: w). Two points (EST05459 between 429.5 and $429.7 \mathrm{~m}$ and EST05522 between 446.9 and $447.1 \mathrm{~m}$ ) initially appeared to be aberrant with values of $1.5 \%$. However, wet 
density measurement in kerosene confirmed the very low water contents of these two samples that are the most calcareous.

The grain densities $(\rho s)$ obtained by He pycnometry vary between 2.50 and $2.75 \mathrm{~g} / \mathrm{cm}^{3}$, and correspond to the values anticipated for a formation composed of clays, carbonates and silicates. The values of water content and He and kerosene ("oil") densities help to calculate the total porosity (Table 3). Two types of calculated porosity can be distinguished:

- "He porosity" calculated from measurements of water content, wet density in kerosene, and grain density obtained by helium pycnometry;

- "Kerosene porosity" calculated from measurements of water content and wet density and grain density in kerosene.

The He- and kerosene-porosity values are higher than those of $\mathrm{Hg}$ porosity. This is because mercury does enter pores smaller than $37 \AA$ (cylindrical pore model). However the proportion of this microporosity can be significant in clay. Two highly calcareous levels at 429 and $447 \mathrm{~m}$, however, display $\mathrm{Hg}$ porosity higher than the He and kerosene values. Two hypotheses could explain this:

- In these levels, the water saturation is perhaps not complete, so that $\mathrm{Hg}$ porosity measures a porosity partly filled with gas;

- A problem in mercury porosity measurements on the two samples.

The three porosity values that are proposed in Table 3 necessarily contain the absolute porosity. $\mathrm{Hg}$ porosity represents the lower limit because microporosity $<37 \AA$ is not measured. The porosity in kerosene represents the upper limit due to possible miscibility of pore water in the kerosene during measurement. Note that by considering these two limits, the median value has a maximal uncertainty of $\pm 2.5 \%$. 


\section{Table 3}

Measurements of specific surfaces by the BET $\mathrm{N}_{2}$ method (Table 3) yield values consistent with the mineralogical composition of the rock. The most calcareous levels give values of bolow, or close to, $10 \mathrm{~m}^{2} / \mathrm{g}$ while the clayey levels give values higher than $30 \mathrm{~m}^{2} / \mathrm{g}$, the highest figure being $39.5 \mathrm{~m}^{2} / \mathrm{g}$.

\subsection{GEOCHEMISTRY}

Major-element analyses are difficult to describe without being redundant with mineralogy, since the mineral phases were quantified using concentrations of major elements (Table $\mathrm{A} 3$ ). Thus $\mathrm{Si}, \mathrm{Al}, \mathrm{Fe}$, and $\mathrm{K}$ indicate silicates and aluminosilicates while $\mathrm{Ca}$ and loss on ignition (LOI) $\left(1000^{\circ} \mathrm{C}\right)$ indicate calcites. Fe enrichment at the base of the formation can be correlated with siderite. $\mathrm{Mg}$ and Ti concentrations vary slightly, like the dolomite and Ti oxide concentrations respectively. S concentrations fluctuate slightly, and only the very low $\mathrm{S}$ in the limestone banks is worth mentioning. Mn and $\mathrm{P}$ concentrations remain close to their respective detection limits $(\mathrm{Mn}=0.02 \%, \mathrm{P}=0.05 \%)$. Na concentrations never exceed the detection limit, or $0.2 \%$.

Trace elements (B, Ba, Be, U, Ce, Co, Cr, Cu, La, Li, Ni, Nb, Pb, Sr, V, Y, Zn, Zr) have very low concentrations in the calcite-rich samples. The formation is thus marked by concentration variations as a function of the carbonate content. Some trace elements such as $\mathrm{B}, \mathrm{Ba}, \mathrm{Ce}, \mathrm{Cu}, \mathrm{Co}, \mathrm{Cr}, \mathrm{Li}, \mathrm{Ni}$, and $\mathrm{Zn}$ increase in concentration with depth, while they remain within the same order of magnitude. $\mathrm{Be}, \mathrm{Nb}, \mathrm{Pb}$ and $\mathrm{Y}$, exceed their detection limits only in the $\mathrm{I} / \mathrm{S}_{\mathrm{R} 1}$ zone. The following trace elements remain below their detection limits in all samples (in mg/kg): $\mathrm{Ag}<0.2 ; \mathrm{Cd}<2$; $\mathrm{Mo}<5$; $\mathrm{Sb}, \mathrm{Bi}$, Sn and $\mathrm{W}<10$; As $<20$. The large body of analytical data on trace elements allows a statistical treatment with reduced centred principal component analysis (PCA). Graphic representation of the 
multiple correlations (Fig. 12) serves to understand how the data are organised and hence clarifies the relations of the trace elements with one another and with the minerals making up the rock. Figure 12 can be viewed as a geographic map considering North at the top. The variations of mineralogical composition are clearly identifiable, with $\mathrm{I} / \mathrm{S}_{\mathrm{R} 0}$ and quartz at $\mathrm{N}$, calcite at $\mathrm{SW}$, and kaolinite and $\mathrm{I} / \mathrm{S}_{\mathrm{R} 1}$ at $\mathrm{SE}$. The accessory minerals mica, feldspar, chlorite, and Ti oxide are separated in the E and distributed along N / SE axis. They are clearly correlated to the content of clay minerals in opposition to the calcite-rich level. Dolomite/ankerite is not correlated with calcite, and does not mark any correlation with the two types of clay.

With the exception of $\mathrm{Sr}$, the trace elements rather display a statistical distribution close to detrital or clayey minerals. Note the very strong correlation between mica and U. Thus U is not present in carbonates, but rather in the detrital minerals or organic matter. $\mathrm{Ti}, \mathrm{Zr}, \mathrm{La}$, $\mathrm{Ba}, \mathrm{Cr}, \mathrm{Ce}, \mathrm{V}, \mathrm{Co}, \mathrm{B}, \mathrm{Ni}$ and $\mathrm{Zn}$, show a statistical behaviour that seems to indicate a strong presence in the detrital minerals such as micas or also linked to siderite. $\mathrm{Li}, \mathrm{Nb}, \mathrm{Y}$, $\mathrm{Pb}$ and $\mathrm{Mn}$, appear to be linked to the kaolinite and $\mathrm{I} / \mathrm{S}_{\mathrm{R} 1} . \mathrm{Cu}$ and $\mathrm{Be}$ display intermediate behaviour between these two types of minerals. $\mathrm{Sr}$ is not correlated with any mineral, although the SEM analyses show that it is trapped in celestite, whose proportion is too small to be detected by XRD.

Note also that $\mathrm{Ce}$ and $\mathrm{La}$ are not particularly correlated with $\mathrm{P}$ or apatite. These elements are more likely trapped in micas than in Ca-phosphates. In other geological context, Ca-phosphates concentrate them significantly. $\mathrm{Zr}$ and $\mathrm{Ti}$ are correlated and have probably the same detrital origin. There is no correlation of sulphur with $\mathrm{Cu}, \mathrm{Zn}, \mathrm{Mn}$, and Fe. These metals are not mostly trapped in sulphides. Iron must be present in severals minerals including phyllosilicates, sulphides and carbonates. 


\section{Figure 12}

\subsubsection{CATION EXCHANGE CAPACITY (CEC) AND EXCHANGEABLE CATIONS}

The samples have an average $\mathrm{CEC}_{\Sigma}$ (Sum of exchangeable cations) of $15.3 \pm 5.0$ meq/100g. The three strongly calcareous beds $(429.6 \mathrm{~m}, 435.9 / 438.4 \mathrm{~m}, 446.9 \mathrm{~m})$ are clearly distinguished (Table 4). In these banks, $\mathrm{CEC}_{\Sigma}$ drop to $3.3 \mathrm{meq} / 100 \mathrm{~g}$. Yet the top of the formation (422.9m) displays non-negligible values of $\mathrm{CEC}_{\Sigma}(13.1 \mathrm{meq} / 100 \mathrm{~g})$. The highest $\mathrm{CEC}_{\Sigma}$ value was obtained in the $\mathrm{I} / \mathrm{S}_{\mathrm{R} 0}$ zone $(22.9 \mathrm{meq} / 100 \mathrm{~g}$ at $463.7 \mathrm{~m})$. A drop in $\mathrm{CEC}_{\Sigma}$ is observed at the $\mathrm{I} / \mathrm{S}_{\mathrm{R} 0} / \mathrm{I} / \mathrm{S}_{\mathrm{R} 1}$ transition. In the $\mathrm{I} / \mathrm{S}_{\mathrm{R} 1}$ zone, the average $\mathrm{CEC}_{\Sigma}$ is $13.5 \pm 0.4$ $\mathrm{meq} / 100 \mathrm{~g}$.

The type of adsorbed cation population is interesting because, to some extent, it reflects the pore water composition. Exchangeable cation proportions are extremely stable in the oxfordian units. Thus $\mathrm{Ca}$, at $46.9 \%( \pm 1.6 \%)$, is the dominant adsorbed cation, following by $\mathrm{Mg}$ at $26.1 \%( \pm 2.1 \%), \mathrm{Na} 18.7 \%( \pm 1.9 \%)$, and $\mathrm{K} 8.3 \%( \pm 1.1 \%)$. The stability of clayey surface chemistry indicates that the relative proportions of $\mathrm{Ca}, \mathrm{Mg}, \mathrm{Na}$ and $\mathrm{K}$ in the pore water are uniform throughout the formation.

\section{Table 4}

\subsubsection{LEACHABLE ANIONS}

\section{$\mathrm{Cl}$ and $\mathrm{Br}$}

The values of leachable $\mathrm{Cl}$ remain in the same order of magnitude throughout the studied interval. The mean of the concentrations is $3.610^{-2} \pm 1.410^{-2} \mathrm{~mol} / 1(1.28 \pm 0.4 \mathrm{~g} / \mathrm{l})$. The calcareous beds at 429 and $447 \mathrm{~m}$ are distinguished by high leachable-Cl contents (Fig. 13). The increase of the $\mathrm{Cl}$ content in the calcareous beds is probably linked to the problem of not complete water saturation. 
The $\mathrm{Cl} / \mathrm{Br}$ ratio is a good tracer of water origin, distinguishing water of marine origin from waters where evaporites have precipitated or have been dissolved. $\mathrm{Cl} / \mathrm{Br}$ ratio helps also to identify mixtures (Fontes and Matray, 1993).

A variation of the $\mathrm{Cl} / \mathrm{Br}$ weight ratio is observed within the formation. At the top of the formation, the first two points with high $(>400) \mathrm{Cl} / \mathrm{Br}$ weight ratios reveal a transition zone between the clayey Oxfordian (C2d) and the calcareous Oxfordian (C3a) (Fig. 13). This is followed by a zone between 436 and $467 \mathrm{~m}$ where the $\mathrm{Cl} / \mathrm{Br}$ weight ratio fluctuates slightly $(334 \pm 42)$ and is closer to a marine ratio $(\approx 300)$. After an increase to a ratio of 515 at 475 $\mathrm{m}$, mean ratios of $236 \pm 33$ are found in the $\mathrm{I} / \mathrm{S}_{\mathrm{R} 1}$ zone from $483 \mathrm{~m}$, which are close to those of the Dogger in the Paris Basin (between 100 and 170) and those measured in the waters at the top of the Dogger of borehole MSE101, or 273 (ANDRA, 1999).

\section{Figure 13}

\section{$\mathrm{SO}_{4}$}

In the leach waters, $\mathrm{SO}_{4}$ values are high with respect to $\mathrm{Cl}$, the mean being $8.2710^{-2} \pm$ $2.8710^{-2} \mathrm{~mol} / \mathrm{l}$. The highest values are located in the alternating marl-limestone zone at the top of the formation (Table 5). The average $\mathrm{Cl} / \mathrm{SO}_{4}$ weight ratio $(0.17 \pm 0.06)$ is quite different from that of seawater (7.1). Such different $\mathrm{Cl}$ behaviour is characteristic of redox mechanisms and dissolution/precipitation, which affected this aqueous species during diagenesis.

In the leach experiments, sulphates can originate from soluble anions in pore water,the dissolution of sulphate minerals (celestite identified by SEM), the oxidation of pyrites, or S complexed by organic matter. It is impossible to state positively that all leached $\mathrm{SO}_{4}$ originates in pore water. Principal component analysis reveals very similar behaviour 
between $\mathrm{SO}_{4}$ and $\mathrm{Sr}$, and no correlation between $\mathrm{SO}_{4}$ and $\mathrm{Ba}$, suggesting a partial origin of $\mathrm{SO}_{4}$ from the dissolution of celestite. Since the experiments were conducted with great care under a nitrogen atmosphere, it is conceivable that pyrite oxidation did not contribute significantly to the leach- $\mathrm{SO}_{4}$. SEM analyses showed that $\mathrm{S}$ was commonly present in large quantities in organic matter. Sulphur trapped by organic matter could potentially be mobilized during the leaching.

\section{Table 5}

\section{$\mathrm{PO}_{4}, \mathrm{I}$ and $\mathrm{F}$}

Aqueous phosphates are leached in detectable amounts in only two samples from the middle part of the formation (Est05620 and Est05646). Iodide ions exceeded the detection limit in the upper zone of the formation between 429 and $453 \mathrm{~m}$ with a maximum of $0.1 \mathrm{mg} / \mathrm{kg}$. Fluorides are detected throughout the formation with a maximum of de 18.9 $\mathrm{mg} / \mathrm{kg}$ at the top of the formation and a mean of $7.0 \pm 3.2 \mathrm{mg} / \mathrm{kg}$.

\subsubsection{REDOX STATE}

The total reducing capacity (TRC) (Table 5) values of Callovian-Oxfordian argillite (4.7 \pm $1.3 \mathrm{meq} / \mathrm{g}$ ) are similar to those measured in the Mont Terri project (Pearson et al., 2003; borehole A6: $4.8 \pm 0.9 \mathrm{meq} / \mathrm{g}$ on average). TRC variations are mainly associated with the calcareous beds where the TRC is lowest, $1.6 \mathrm{meq} / \mathrm{g}$, while the highest values are observed at the top $(7 \mathrm{meq} / \mathrm{g})$ and in the $\mathrm{I} / \mathrm{S}_{\mathrm{R} 0} / \mathrm{I} / \mathrm{S}_{\mathrm{R} 1}$ transition zone $(6.75 \mathrm{meq} / \mathrm{g})$. The range of variation is narrow.

With the exception of $\mathrm{Mn}$, the species determining the reducing character of the rock (TOC, Fe and $\mathrm{S}_{\mathrm{tot}}$ ), are well correlated with the general TRC value.

\subsubsection{ORGANIC MATTER}


In the formation, organic matter was identified as accumulations associated with pyrite framboids or bioclasts (Fig. 6). It is generally dispersed in the clayey matrix of these rocks, forming darker beds in optical microscopy where it is concentrated.

SEM analyses of organic matter reveal a substantial presence of sulphur. This correlation between sulphur and organic matter is not confirmed by other evidence.

TOC content ranges from 0 to $0.7 \%$ between 423 and $450 \mathrm{~m}$, with the exception of sample Est05474 at $432.2 \mathrm{~m}(\mathrm{TOC}=1.1 \%)$. For all other samples, the TOC contents ranged from 0.5 to $0.9 \%$.

The correlation matrix calculated for the formation shows the absence of any correlation between TOC and other elements. The two strongest correlations concerning TOC are with CEC and total specific surface, revealing the strong link between organic matter and clay surfaces.

\section{CONCLUSION}

Geologically, the upward evolution of the formation is characterised by:

- Increasing shaliness (with ordered mixed-layer illite/smectite $\mathrm{I} / \mathrm{S}_{\mathrm{R} 1}$ ), accompanied by a decrease in carbonate content and an increase in silt proportion, up to a maximum clay zone (MCZ), corresponding to a maximum flooding surface;

- Decreasing shaliness (with disordered mixed-layer illite/smectite $\mathrm{I} / \mathrm{S}_{\mathrm{R} 0}$ ), an increase in carbonate content and a decrease in silt proportion above this zone, up to the top of the host formation

The mineralogical composition of the host layer only varies slightly within the area of the site, but within individual units slight variations can occur in different directions. 
Grain size composition of the Callovian-Oxfordian is slightly more variable than the mineralogical variability. Between boreholes EST103 and EST205, differences of 6 to 7\% are observed in the proportions of both clay and the silt contents.

However, the above statements merit great caution when interpreting the variability of the Oxfordian units at the scale of the site, due to the slight differences observed between boreholes, the small number of boreholes considered that cannot be termed statistically representative, and the relatively small number of samples analysed.

The data collected from borehole EST205 establish an even more complete and accurate geochemical log than those produced by previous operations. The coring and core packaging procedure provided samples that were little or not at all disturbed by oxidation and hence can be considered as representative of the in situ material. A total of 29 core samples from borehole EST205 was analysed, one every $3 \mathrm{~m}$, for physical measurements (water content, porosity, density, specific surface) and geochemical measurements (elementary analyses of major- and trace-elements, exchangeable cations and CEC, leachable anions, redox state, and organic matter).

The range of mineral-geochemistry and physical-measurement tools deployed was consistent with the mineralogical variations observed and particularly with the occurrence of calcareous seams at the top of the Callovian-Oxfordian, and more clayey levels in the lower portion of the formation. The characterisation tools used for compiling the geochemical and mineralogical logs also helped to quantify the mineral phases with narrower ranges of uncertainty than in previous work.

The range of porosity variations determined previously for the Callovian-Oxfordian rocks was confirmed. A coupling of different techniques used for measuring or calculating porosity was used to estimate the range of uncertainty for the total porosity. The values of 
BET specific surface with nitrogen confirmed the clayey nature of the rock and are consistent with previously determined figures.

A statistical analysis of major elements, trace elements and minerals helped to grasp the relations between trace elements and their potential mineralogical traps.

Anion-leaching experiments established the $\mathrm{Cl}$ concentration and $\mathrm{Cl} / \mathrm{Br}$ ratio profile. The $\mathrm{Cl} / \mathrm{Br}$ ratios from the middle of the Callovian-Oxfordian are close to a marine ratio, providing an interesting indication of the origin of the waters. The Dogger signature at the base of the formation can be explained by diffusion process.

Data on exchangeable cations and leached anions roughly indicated the slight variation in composition of the water chemistry in the Callovian-Oxfordian formation.

Measurements of total reducing capacity were taken for the first time on the CallovianOxfordian argillite.

These values of anion-leaching, exchangeable cations, TRC can contribute to constrain the future work on the pore water chemistry.

Elementary analysis with a scanning electron microscope coupled with X-ray diffraction and optical microscopy, provided a list of minerals in the argillite whose chemical composition was determined. For example, we now know that no true dolomite exists in the formation, but rather magnesian calcite and calcium-rich dolomite. These characterisations also helped to confirm the absence of iron oxides. This precise list of well characterised minerals is also necessary to the models of sorption and migration of the radionuclides in this formation and to determine the pore water chemistry.

\section{ACKNOWLEDGEMENTS}


This work was financed by ANDRA (URL Bure Site). The authors acknowledge the mineralogists of ERM, the chemical analysts of BRGM and the geologist team of J.C. Corbin (GEO-RS). Dr Thomas Pletsch is thanking for his considerable work to improve the manuscript. 


\section{REFERENCES}

ANDRA, 1999. Référentiel géologique du Site de Meuse / Haute-Marne. Rapport ANDRA A RP ADS 99-005/B.

Bath, A.H., Pearson, F.J., Gautschi, A. \& Waber, H.N., 2001. Water-rock interactions in mudrocks and similar low permeability material. In: CIDU, R. (Ed.): Water-Rock Interaction: Proceedings of the 10th International Symposium on Water-Rock Interaction, Villasimius, Sardinia (Vol. 1, p. 3-12). - A.A. Balkema, Rotterdam.

Bertrand, L., Gaucher, E., Heitz, J.F., Matray, J.M., Bois, A.P., Fourmaintraux, D., Gros, Y., Côme, B., Robin, P., Robelin, C., 2001. Laboratoire de recherche souterrain Meuse/Haute-Marne - Lot 3 - Forage d'investigation géologique complémentaire Rapport de synthèse ANDRA D RP 0ANT 01-022/B.

Beaufays, R., Bloomaert, W., Bronders, P., De Canniere, P., Del Marmot, P., Henrion, P., Monsecour, M., Patyn, J. \& Put, M., 1994. Characterisation of the Boom Clay and its multilayered hydrogeological environment (Fin. Rep., EUR 14961 EN). - Europ. Com. Office of Publ., Luxembourg.

Caillaud, J., Bouchet, A., Cassagnabère, A., Marchand, D., Parneix, J.C., Rassineux F., Sammartino S., 2000. Laboratoire de recherche souterrain de Meuse/Haute-Marne Analyses minéralogiques et géochimiques forage EST205 - Rapport ANDRA. Rapport final d'opération B RP 0ERM 01-001/A

Calvert C.S., Palkowski D.A., Pevear D.R. (1989) - A combined X-ray powder diffraction and chemical method for the quantitative mineral analysis of geologic samples. In : C.M.S. Workshop Lecture, Vol. 1, Quantitative Mineral Analysis of Clays. D.R. Pevear \& F.A. Mumpton Eds., Boulder, Colorado, 153-166. 
Deer, W.A., Howie, R.A., Zussman, J., 1992. An introduction to the rock-forming mineral. $2^{\text {nd }}$ ed. Longman, Essex, G.B., 696p.

De Windt, L., Cabrera, J. \& Boisson, J.-Y., 1998. Hydrochemistry in an indurated argillaceous formation (Tournemire tunnel site, France). In: Arehart, G.B. \& Hulston, J.R. (Eds.): Water-Rock Interaction: Proceedings of the 9th International Symposium on WaterRock Interaction, Taupo, New Zealand (p. 145-148). - A.A. Balkema, Rotterdam.

Donsimoni M. (1981) Le bassin houiller lorrain - Mémoire. BRGM, 117, 100p, 15 pl.

Fontes, J.-Ch., Matray, J.M. (1993) Geochemistry and origin of formation brines from the Paris Basin, France. 1. Brines associated with Triassic salts. Chem. Geol., 109, 149-175.

Foster M.D. (1969) Studies of celadonite and glauconite. Geological survey professional paper 614F, U.S. gov. Printing office, Washington.

Griffault L., Merceron T., Mossmann J.R., Neerdael B., De Cannière P., Beaucaire C. Daumas S. Bianchi A., Christen R. (1997) Acquisition and regulation of the water chemistry in clay environment. Archimede project CEC Final report. $4^{\text {th }} \mathrm{R} \& \mathrm{D}$ Programme on Management and Storage of Radioactive Waste.

Hendricks S.B., Ross C.S. (1941) Chemical composition and genesis of glauconite and celadonite ; Am. Miner., 26, 683-697.

Newman A.C.D. and Brown G. (1987) The chemical constitution of clays in : Chemistry of Clays and Clay Minerals. A.C.D. Newman Ed., Miner. Soc., London, 1-128.

Pearson J., Arcos D., Bath A., Boisson J.Y., Fernandez A.M., Gaebler H.E., Gaucher E.C., Gautschi A., Griffault L., Hernan P., Waber H.N. (2003) Geochemistry of water in the Opalinus Clay Formation at the Mont Terri Rock Laboratory. Reports of the Swiss Federal Office for Water and Geology. Geology Series, No 5.450 p. in press.

Petitjohn F.J., Potter P.E., and Siever R. (1972) Sand and Sandstone. New York : Springer. 
Reynolds R.C. (1989) Principles and techniques of quantitative analysis of clay minerals by X-ray powder diffraction. In : CMS. Workshop Lecture, Vol. I. Quantitative Mineral Analysis of Clays, D.R. Pevear and F.A Mumpton Eds., Boulder, Colorado, 3-36.

Thury, M. and Bossart, P. (1999) Mont Terri Rock Laboratory. Results of the Hydrogeological, Geochemical and Geotechnical Experiments Performed in 1996 and 1997 (SNHGS Geol. Rep. 23). - Swiss Nat. Hydrol. and Geol. Surv., Bern.

Velde B. (1985) Clays minerals: a physico-chemical explanation of their occurence. Developments in Sedimentology, 40, Elsevier, Amsterdam, 426p.

Weaver C.E. (1989) Clays, Muds and Shales. Devel. Sedim., 44, Elsevier, Amsterdam, 819 p. 